\title{
長径間ゲートの振動特性に関する研究 \\ A STUDY ON VIBRATION PHENOMENA OF LONG-SPAN GATES
}

\author{
上田幸 彦*・荻原国 宏** \\ By Yukihiko UEDA and Kunihiro OGIHARA
}

\section{1.はじめに}

近年工業用水，上水道用水および農業用水などの水資 源を確保するために, 河川中流域や河口付近を河川全幅 にわたって締切り，せきを兼ねるような長径間ゲートが 数多く設置されるようになって以来, 流水に伴うこの種 のゲート振動は非常に重要な問題となり, 注目されてい る.

一般に長径間ダートといっても，その用途に応じてい ろいろなタイプのものが考えられ，ここで対象としてい るのは, ゲート下端から放流させるタイプの 1 段式長径 間シェル構造ローラゲート（以下 1 段式ローラゲートと 略称する）およびゲート上部から越流させるタイプの 2 段式長径間シェル構造ローラゲート（以下 2 段式ローラ ゲートと略称する）であり，これらは，いずれも通常よ く用いられる長径間ゲートである.

1 段式ローラゲートの振動現象は, Petrikat ${ }^{1)}$ をはじ めとしていく人かの人によって基礎的な研究 ${ }^{2), 3)}$ がなさ れてきたけれども, 流水と構造物の相互作用によって振 動する水力弾性 ${ }^{4)}$ とよばれる現象に属するため, 実際に 使われているようなシェル構造タイプの振動現象につい ては, 要因分析が困難となり,いまだ末解明な点が多い.

一方， 2 段式ローラゲートの振動現象については，ま だ研究例 ${ }^{5)}$ が少なく, 特に上下段扉間の中間止水部から の漏水に伴う振動については, その現象がほとんど解明 されていない現状である.

筆者らは，上記の 1 段式ローラゲートの下端放流およ び 2 段式ローラゲートの中間止水部からの漏水に伴う振 動現象を解明すべく, 主として大型弹性相似模型による 実験により研究し, また, 理論解析モデルと実験結果と の比較を行った。

\footnotetext{
* 正会員 不川島播磨重工業 (株) 鉄構基本設計部課長補传
}

** 正会員 T博 東洋大学:教授 T学部土木工学科

\section{2. 実験装置および実験方法}

実験に用いられた水路は幅 $2.5 \mathrm{~m}$, 深さ $1.8 \mathrm{~m}$, 長さ $43.5 \mathrm{~m}$ の鉄筋コンクリート製で，側壁の 1 部に強化ガ ラスでつくられた観測空が取付けられている．水路上流 端には送水管と連結した分散管が設けられており，下流 端には下流水位調節用の電動式鋼製ゲートが設置されて いる.

模型ゲートは, ゲート底板を水平面より $20^{\circ}$ 傾斜さ せた径間 $41.4 \mathrm{~m}$ ，高さ $5.0 \mathrm{~m} ， 1$ 段式ローラゲートお よび下段扉を上流側，上段扉を下流側に配置した径間 $41.4 \mathrm{~m}$, 高さ $7.8 \mathrm{~m}$ (上段扉高 $4.05 \mathrm{~m}$, 下段扉高 4.35 m) の 2 段式ローラゲートをそれぞれ想定原型とし, 水 路幅の関係から縮尺 $1 / 20$ の弾性相似模型とした.

この弾性相似模型は, 幾何学的に相似した部材と弾性 的に相似した部材を組合せる方法で製作された.すなわ ち，模型ゲートの弾性は，重心位置に配置された高力 アルミ合金 (A 3 P 4-T 3, 比重量 $2.77 \mathrm{t} / \mathrm{m}^{3}$, ヤング率 $\left.728 \mathrm{t} / \mathrm{cm}^{2}\right)$ 製の引抜中空角形弾性棒により相似させ, ス キンプレート, 頂板, 底板および背板で構成された扉体 シェル (ゲート本体) の幾何学的形状は, 透明で加工精 度のよいアクリル樹脂によって相似させた.この場合, 屝体シェルはアルミ製弾性棒の剛性に関与しないように ゲート全長を 16 ブロックに分割し, 各ブロック間のす きま $2 \mathrm{~mm}$ は非常に薄いゴム (厚さ $0.010 \mathrm{~mm}$ ) で接合 することによって, 各ブロック間の漏水は完全に防止さ れた. また, 模型ゲートの質量相似は,アルミ製弾性棒 と扉体シェルを構成しているアクリル樹脂によって満足 させた。

2 段式ローラゲートの場合には, 上段扉に発生する振 動に着目しているので, 弾性相似模型は上段屝のみとし 全閉状態となっている下段扉は, 外郭形状のみ幾何学的 に相似したアクリル製模型とし水路底面に固定された. 
図一1，2 は模型ゲートの外郭形状を示したものである.

上下段扉間の中間止水部模型は, 図一2 に示すよ5 に, 水密ゴムの代りに厚さ $2 \mathrm{~mm}$ のアクリル樹脂が用 いられ，そのすきまは自由に変えられるようになってい る.

ところで, 模型により振動を計測する場合には, 応答 特性に大きな影響を与える減衰定数を模型と原型の間で 一致させなければならないことは当然のことであるが， 実物ゲートの減衰值は, 種々の要因が複雑に組合わさり 定量的評価ができないのが現状である.そこで，ここで は粠造減衰をできるだけ小さくして危険側の実験結果が

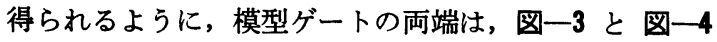
に示すよらに, ワイヤロープに対応する板ばねと連結し た愻垂吊棒とローラの取付位置に配置された水平支持棒 により支承された. したがって, ゲート両端では, 鉛直 方向のみ自由に運動できるようになっている.

次に，実験状況であるが，1 段式ローラゲートの場合 上流水樑 $h_{\boldsymbol{u}}$ は常に一定にしてゲート開き高 $a$, 下流水 深 $h_{d}$, ゲートリップ形状, シル形状, スキンプレート の配置および板ばね定数などを変え， 2 段式ローラゲー トの場合には，やはり上流水深を一定に保ちながらゲー 卜開き高(ここでは，上流水面から上段扉天端までの下 り量を(5), 下流水深, 水密板のすきまおよび水密板 の取付位置などを種々変化させて実験が行われた. ま た, これによって発生してくる振動は, 径間中央部と側 部にセットされた変位計 (日本測器製 DM-002 型, 周
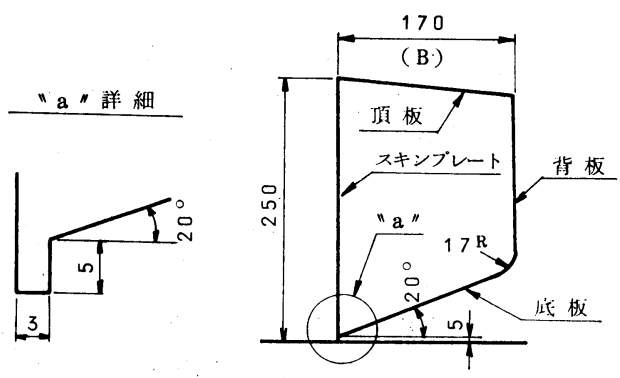

图一1 1 段式ローラゲート模型外部形状

“a”詳細

(中間止水部)
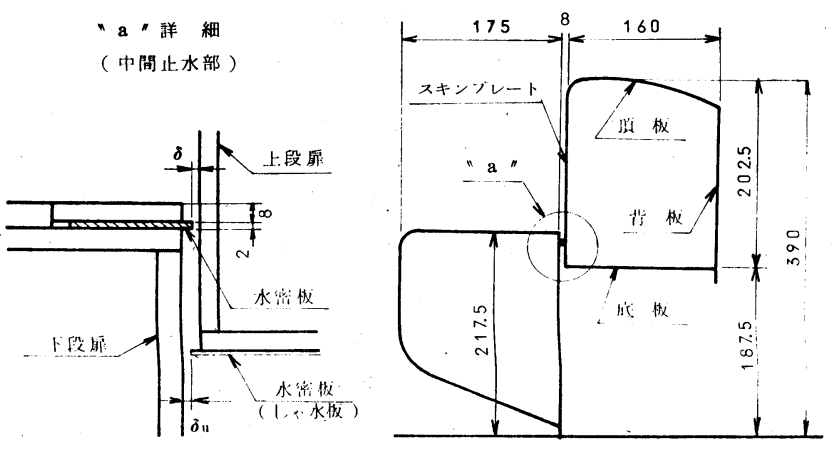

图一2 2 段式ローラゲート模型外郭形状
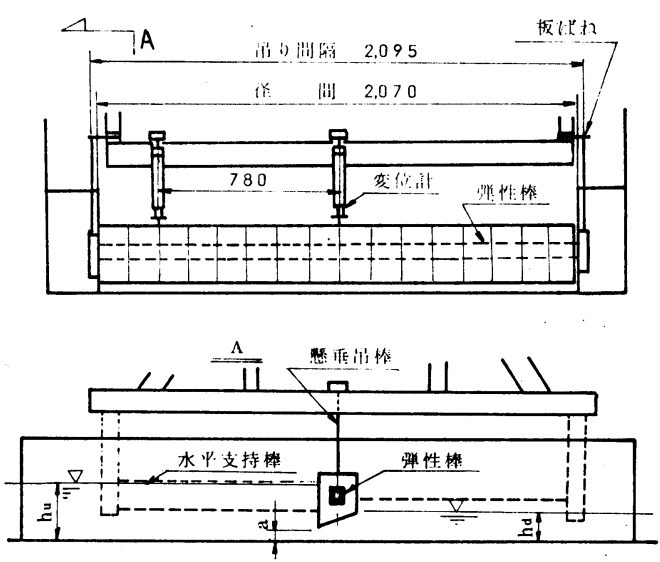

図一31 段式ローラゲート模型支持方式
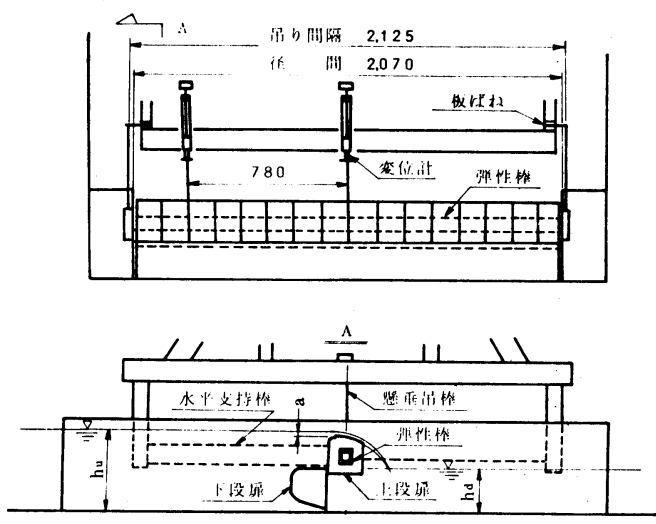

図-42 段式ローラゲート模型支持方式

波数側定範囲 0 10 kc/s) により検出し, 電磁オッシロ グラフに記録された.これらの測定結果については, す べて実物に換算し次の実験結果のところで述べうう.

\section{3. 実験結果}

流水に伴ら振動を計測するに先だち, 空中においてゲ ートの犋量, 曲げ刚性, 板ばね定数, 固有振動数 (1 次）および粘性減衰定数が計測された。 その結果が 表 -1 に示されている. また, 図一5 には, 静水 中においてゲートに自由振動を与え，その変位 曲線から求められた粘性減衰定数と没水度の関 倸が示されている.

\section{（1）．下端放流による1 段式ローラゲートの 振動特性}

a）流れの状況と振動の関係

まず下端放流に伴って発生してくるゲートの 振動は, 流れの状況によってどのように変わっ てくるかを調へてみる. 上流水深を一定 $\left(h_{u}=\right.$ 
$5.0 \mathrm{~m})$ にし, ゲート開度や下流水深を広範囲にわたっ て種々変化させこれによって発生してくる径間中央の 振幅および振動数を下流水深との関連において整理した 結果が，それぞれ 図一6 および図一7,8である.図一

衰一1

\begin{tabular}{|c|c|c|}
\hline 項 目 & 1 段式ローラダート & 2 段式ローラゲート \\
\hline 筧 $\left(\mathrm{K} g-\mathrm{S}^{2}-\mathrm{cm}^{-1}\right)$ & 159.2 & 231.8 \\
\hline 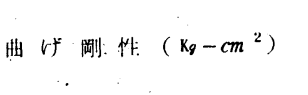 & $\begin{array}{l}\text { E I } x=117.6 \times 10^{12} \\
\text { E I Y }=91.7 \times 10^{12}\end{array}$ & $\begin{array}{l}\text { E I } x=117.6 \times 10^{12} \\
\text { E I Y }=91.7 \times 10^{12}\end{array}$ \\
\hline 极战权分数 $(\mathrm{K} g / \mathrm{cm})$ & $\begin{array}{l}\mathrm{k}_{1}=101,720 \\
\mathrm{k}_{2}=26,560\end{array}$ & $\mathrm{k}=9.7,080$ \\
\hline 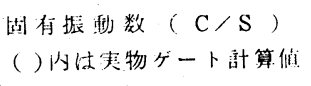 & $\begin{array}{l}k_{1}: f a=3.5 \quad(3.8) \\
k_{2}: f a=2.6\end{array}$ & $\mathrm{fa}=3.0 \quad(3.1)$ \\
\hline 粘性减铱赑数 & $\begin{array}{l}k_{1}: h a=0.0036 \\
k_{2}: h a=0.0066\end{array}$ & $h a=0.0042$ \\
\hline
\end{tabular}

7, 8 には, 減衰自由振動の変位曲線から求められた流水 中における固有振動数も示されている. また，図一9 は 流況変化曲線であり，これによってゲート下流側の流れ の状態が判別できるわけである.すなわち，放流条件が 図一9 の曲線よりも左側の領域に くれば，ゲートリップ直下から流 出水脈が射流となる自由流出状 態, 右側にくれば, 下流水深が跳 水の対応水深よりも高い潜り流出 状態，ちょうど曲線上にくれば, 跳水の始端がゲートリップに接す るような遷移流出状態となる.

これらの図より, 次のことが判 明する.

(1) 上流水深とゲート開度を一 定にしておいて，下流水深を次第 に増してくると, 流れの状況が自 由流出から遷移流出さらに潜り流 出人と変化してくるが, 自由流出 状態および遷移流出状態であれ

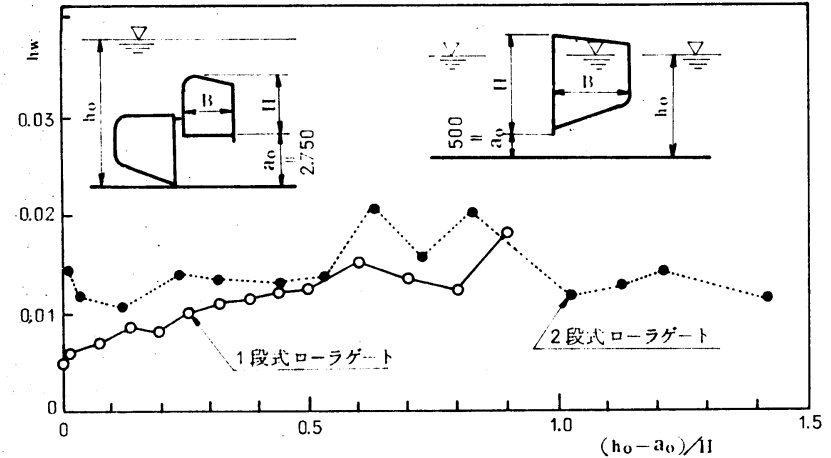

图一5 解水中における娍挔定数 $h_{W}$

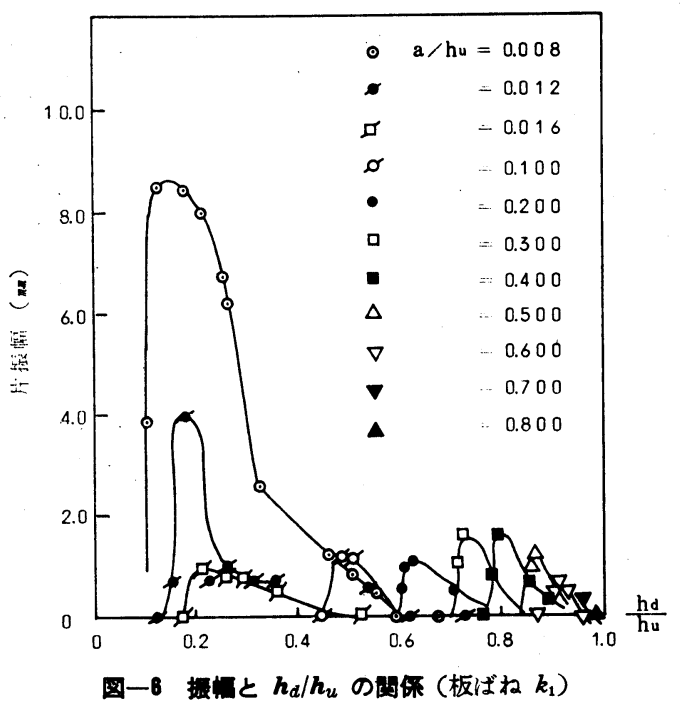

ば，流水により発生する振動はきわめて小さい. これは自由流出状態の場合には流れが常にリップ の上流縁からはく離しリップ下面に干渉しないこ と, 遷移流出の場合には, 跳水表面渦の不規則性 によるものと考えられる.

(2) 遷移流出状態より下流水深が徐々に增して きて, ゲート底板が接水するような潜り流出状態 になると，振幅は増大してくる. しかし，下流水 深がさらに増えてきて背板が接水するような流況 になってくると, 振幅は再び減少してくる. した がって，上流水深を一定にしてゲート開度と下流 水深を種々変化させると, 各開度ごとに振幅のピーク值 が存在することになる。

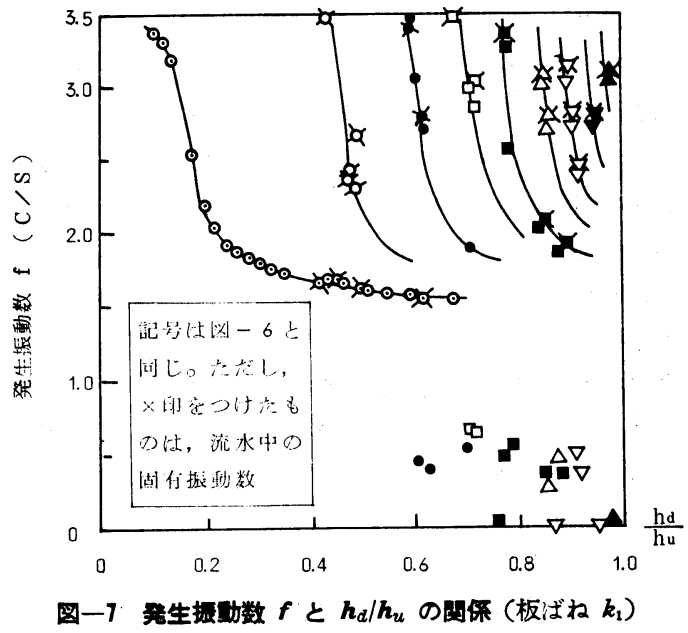




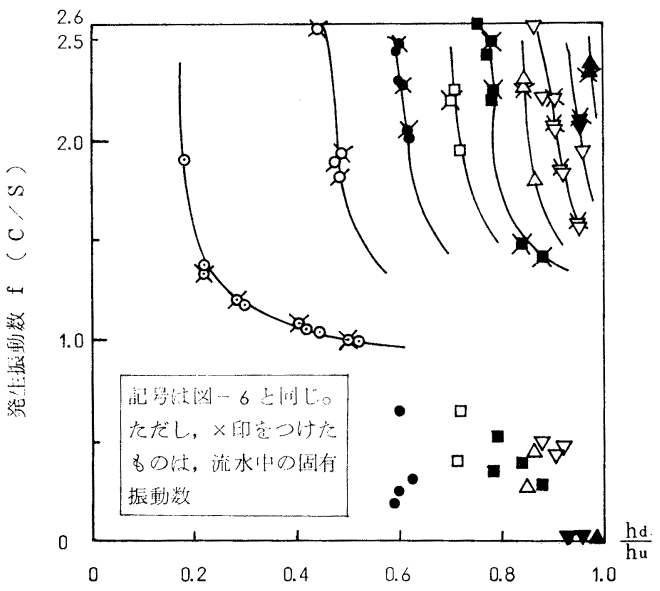

図一8 発生振動数 $\boldsymbol{f}$ と $\boldsymbol{h}_{d} / \boldsymbol{h}_{u}$ の関係 (板ばね $\left.k_{2}\right)$

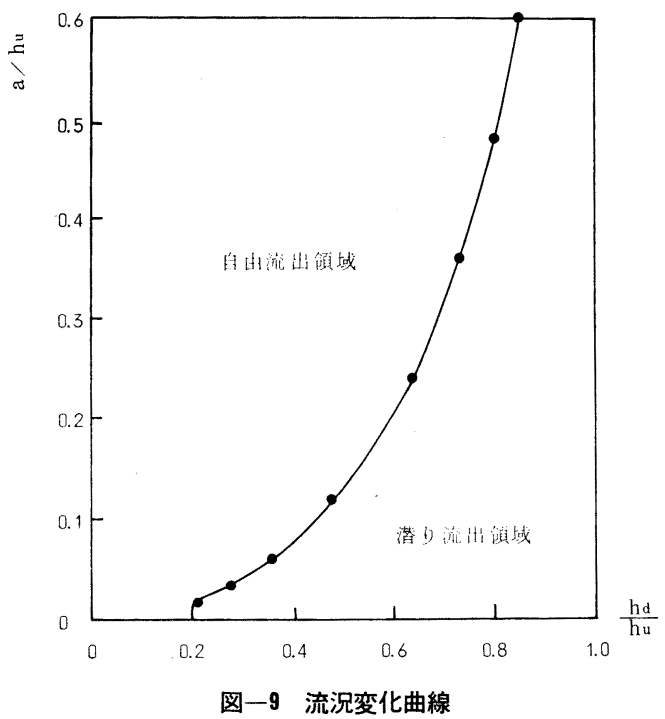

このピーク值が発生するときの振動は, 開度 $a / h_{u} z$ 0.1 の場合と $a / h_{u} \approx 0.01$ の微少開度の場合を比較する とその特性がまったく異なっている，すなわち，前者は $0.7 \mathrm{c} / \mathrm{s}$ 以下の低周波成分と固有振動数にほぼ一致した 共振成分を含んだ振幅の小さい比較的不規則な 1 次振動 である（図一10 (a))。低周波成分の振動数は, 系の固有 振動数のほぼ $1 / 2$ 以下となり, その振幅（包絡線の中 心線の振幅）は共振成分のものと同程度かこれより小さ い. 図一6 に示した振幅は共振成分の值である.また, この前者の振動が発生するときには, 板ばね $k_{1}$ と $k_{2}$ の両方に损いて低周波成分はほぼ同じ振動数をもってお り,さらにゲート直下流側において,これとほぼ同じ周 期をもつかなり激しい波動が観測されている．したがっ て, この種の低周波振動は, 振動系に関係なく, 主とし てゲート直下流側に生ずる波動がゲート底板に作用する ことにようて誘起される強制振動であるを考えることが
できる．共振振動は，この波動とゲートの動きに位相の ずれが生じたときに発生する過渡的な振動ではないかと 考えられる. 写真一1 はゲート直下流側に波動が発生し ているときの状況を示したものである.

次に後者の振動であるが, これは $0.1 \leqq h_{d} / h_{u} \leqq 0.5$ の潜り流出状態において発生する 1 次の規則振動（図一 10 (b)) で, その振動数は, 放流条件が同じ場合にも, 板ばね $k_{1}$ と $k_{2}$ で異なっており, 系の固有振動数にほ

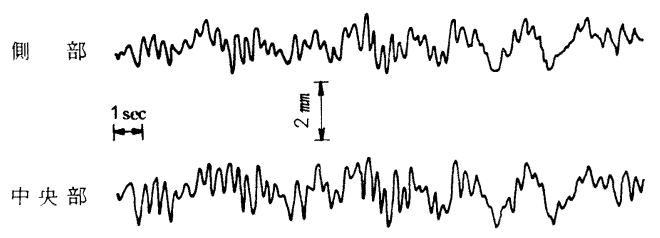

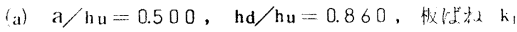

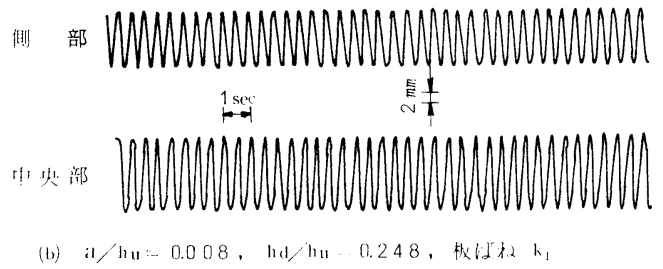

図一10 下端放流に伴う振動記録波形

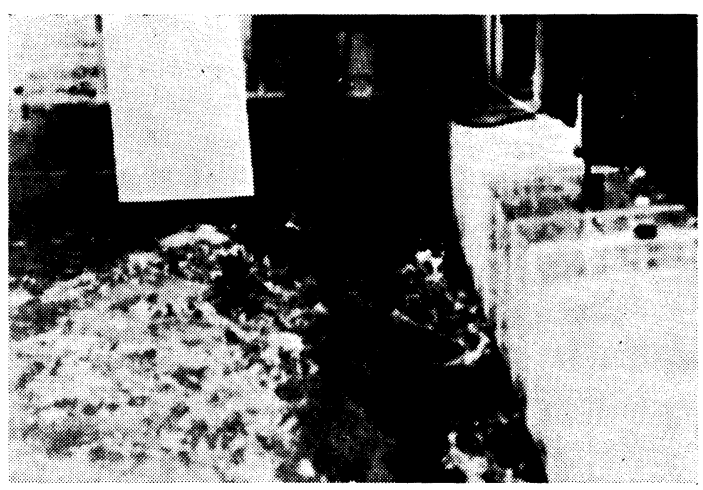

写真一1 ゲート直下流の流況 $\left(a / h_{u}=0.60, h_{d} / h_{u}=0.91\right)$

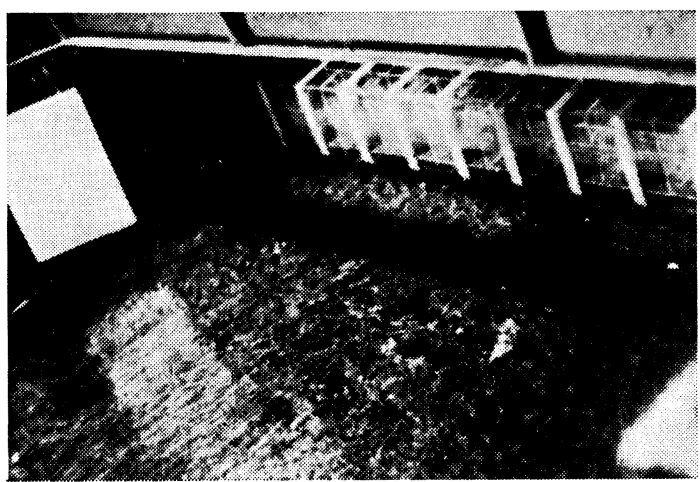

写真一2 ゲニト直下流の流況 $\left(a / h_{u}=0.008, h_{d} / h_{u}=0.30\right)$ 
ぼ一致している．そして振幅は前者の場合すなわち波動 によって起こる振動に比べて著しく大きい. しかしなが ら, ゲート下流側の水面は静稳で, ゲート底板付近にわ ずかに波面がみられる程度である（写真一2）.

したがって, 微少開度におけるこの種の振動は, 明ら かに前者のような波動によって誘起される強制振動では なく，振動系自体の影響を受ける自励振動であるといえ る.

図一11 は縦軸に $\left(h_{d}-a\right) / h_{u}$, 横軸に $a / h_{u}$ をとって 自励振動と強制振動の発生領域を示したものである.

b）微少開度時に発生する規則振動の特性

前項 a) において, 微少開度で放流すると振幅の大き い自励振動が発生することを述べた.ここでは, その特 性についてさらに詳しく調べてみる。

まずゲートリップの形状と振動の関係を把 握するために, リップの長さを種々変化させ た場合, リップ下端を下流に向って $45^{\circ}$ 傾斜 させたシャープエッジリップにした場合, さ らにスキンプレートを下流側に配置した場合 に上流水深 $h_{u}=5.0 \mathrm{~m}$, 開度 $a / h_{u}=0.008$ のもとで計測された径間中央の振幅および振 動数を下流水深と関連つけて整理した結果が 図一12 に示されている.この図から，リッ プ下面がフラットである場合には，下流水深 が上流水深の $20 \%$ 付近に達したときに振幅 が最大となり, その值はリップが長いほど大 きくなる傾向がみられる.

また，リップを $45^{\circ}$ 傾斜のシャープエッ
考えられる.

したがって，このような場合には，屝体そのものが 1 種の弾性リップであると解釈できるので, リップを できるだけ薄くし，かつシャープエッジにするという Petrikat ${ }^{6)}$ の振動低減策をシェル構造ゲートに適用する ことは, 構造強度上不可能なことになる.

次に, シルが振動に与える影響について調べてみる. 前と同じ条件のもとで台形シルの形状やその設置位置 を変えた場合に測定された径間中央の振幅, 振動数と下 流水深の関係を示したのが 図一13 である.

これより，ゲートリップの直下に台形シルを設けた場 合には, 水平水路床の場合とほとんど同じょうな振動を 発生することがわかる. しかし，台形シルをリップより

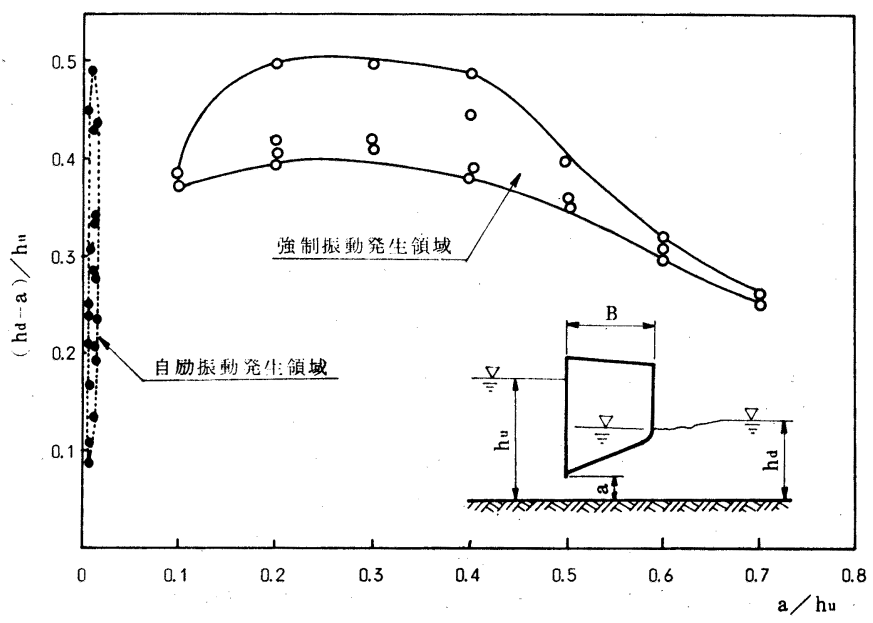

図一11自励振動と強制振動の発生領域

ジにした場合にも同しような振動 を発生することがわかる.すなわ ち, 流れのはく離点をリップの下 流縁にもってきても, フラットリ ップの場合と同様な振動が発生す るわけである.

さらに, スキンプレートが下流 側に配置された場合には,リップ 下端がフラットであるにもかかわ らず, 振動はほとんど発生しない ことが認められる.

これらの事実は, 振動の発生源 がリップ下面にあるのではないこ とを示すものである. 換言すれ ば, この種の振動はリップ下面へ の流水の吸着によって起こるので はなく,リップより下流の不安定 な圧力変動がゲート底板に作用す ることによって誘起されるものと
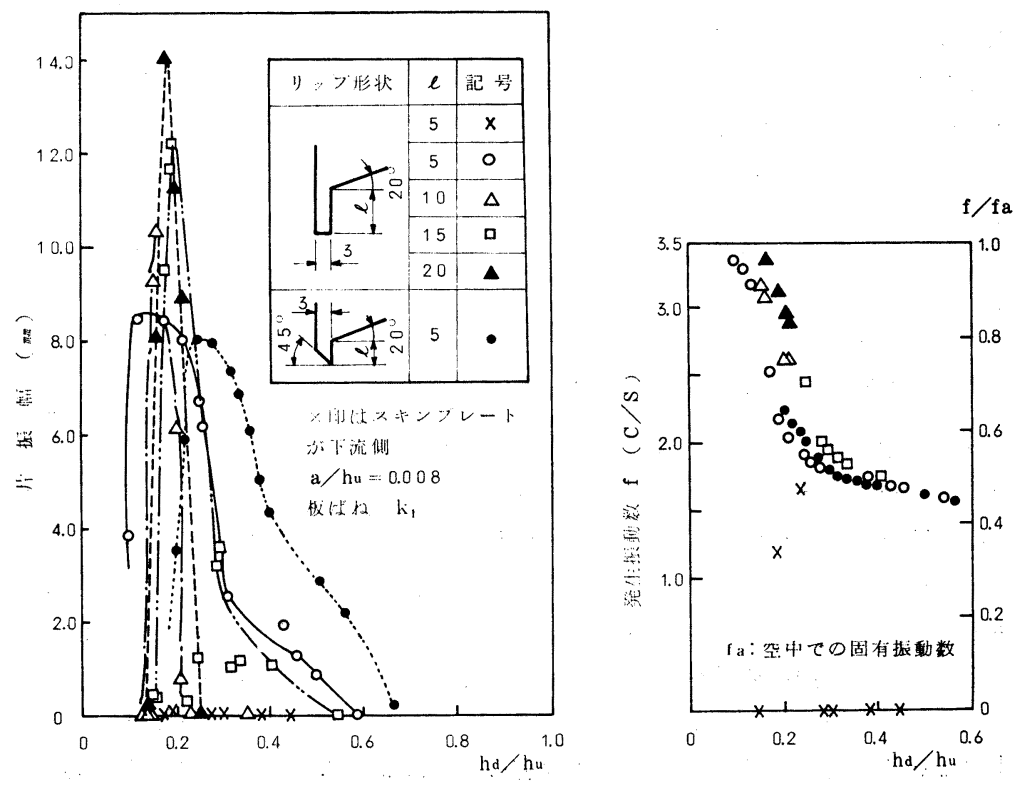

図一12 ゲートリップの形状と振的の閣係 

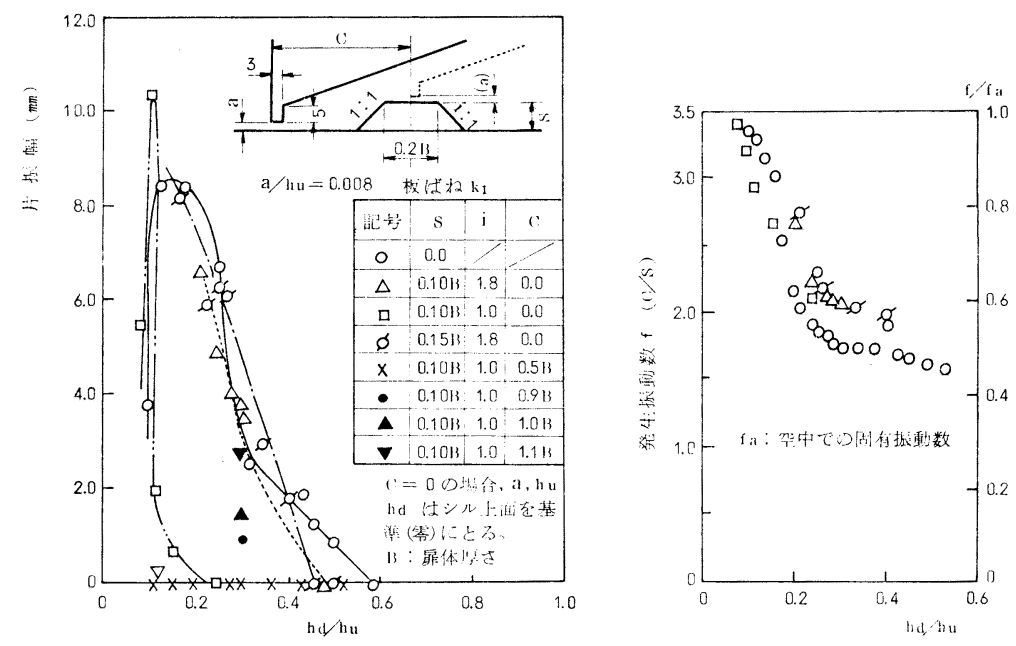

図一13 シルの形状や設置位置が振動に与える影響
段扉スキンプレート下端から下 流水面までの深さ $h_{T}$ を種々変 化させて計測した径間中央の振 幅と $h_{T} / H$ ( $H$ : 上段扉高さ) の関係を整理すると図一14の ようになる.ここにすきま $\delta$ とは, 下流水位が上段扉スキン プレート下端より低いときの径 間中央における水密板先端と上 段扉スキンプレート間の間缯で ある.これより次のことがわか る.

(1) 下流水位が上段扉スキン プレート下端より低い場合に は, 振動は発生しない。これ は, 水密板からの流出水脈が射
下流のゲート底板直下に設けると，振動は著しく低減 し，特にリップより $0.5 \mathrm{~B}$ (B：ゲートの厚さ) 下流の 位置にシルが配置されると，この種の振動は完全に防止 される。

以上述べてきた微少開度における規則振動の特性より この種の振動の発生原因は, リップより流出する薄い水 脈の不安定性にあると考えられる.すなわち，リップよ り流出する薄い水脈は，下流水位が低く自由流出状態で あれば下向きに噴出し，水路底面に沿う安定した露出射 流水脈となるが，下流水位が上昇してくると，この水脈 は上方へ向うようになりある限られた下流水位の範囲内 においてはゲートのわずかな動きによって水路底面に沿 って流れたり，流水表面に向って流れたりする不安定な 状態になると考えられる.

したがって，この種の振動を防止するには，ゲート底 板下の流れの安定化をはかることが必要であり，それに はゲート底板直下に前面傾斜 $1: 1$, 高さ $0.1 \mathrm{D}$ 以上の シルを設ける方法およびスキンプレートを下流側に配置 し，流れのはく離点をゲートの下流縁に固定する方法が ある・

\section{（2）漏水に伴う 2 段式ローラゲートの振動特性}

上下段扉間の中間止水部からの漏水に伴う振動特性を 明らかにするために，ここでは，中間止水部のすきま， ゲート開度，下流水深㧍よび水密板の取付位置の影響に ついで検吋された，以下，これらについて順を追って説 明する.

\section{a）すきまと振動の関係}

㵐水に伴ら振動が，中間止水部のすきまとどのような 関係にあるかを調べるために，まず水密板を下段扉に取 付け，上流水深を一定 $(7.8 \mathrm{~m})$ として，すきま $\delta$ と上
流となり，上段扉スキンプレートに沿って流下する場合 には振動が発生しないことを示すものであり，ちょうど （1）において述べた自由流出時の場合と類似の現象とい える・

(2) すきま $\delta$ が上下段扉のスキンプレート間隔 $\delta_{0}(=$ $210 \mathrm{~mm}$ ) の約 $1 / 2$ 以上で亦机ば, 振動は発生しない.

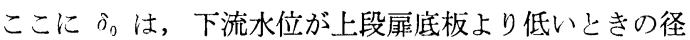
間中央での值である.

(3) 漏水により上段扉に振動が発生するのは, $\delta \leq \delta_{0} / 3$ で，しかも下流水位が上段扉スキンプレート下端より高 くなってきたときである.したがって，漏水に伴う振動 は, 水密板より下側における上下段扉のスキンプレート で囲まれた流路内の空気が，上部から流下する漏水によ って連行誘出され, その流路内が充水されてしまうとき に発生するわけで, 励振源はその流路内に存在する. し たがって,この種の振動は従来報告》 されているような 水密ゴム自身の自励振動によって誘起される振動ではな い.これがこの振動現象の特徵である.

(4) 漏水によって生ずるこのゲート振動は, 振幅のき わめて大きい 1 次の規則振動である (図一15). また, 振動発生時には, 上流水面にゲートの発生周期に等しい 周期をもった表面波が観測されている（写真一3）.

b） ゲート開度と下流水深が振動に与える影響

ここでは，水密板を下段扉に取付け， $\delta / \delta_{0}=1 / 3$ の状 態でゲート開度や下流水深を種々変化させたときの振動 特性を調べてみる. 径間中央の振幅と振動数を, それぞ れ $h_{T} / H$ および $h_{d} / h_{u}$ と関連させて整理した結果が 図一16，17 である。図一18 には, 縦軸を $1-h_{T} /(H+$ $a)$, 横軸を $l_{0} / \delta\left(l_{0}\right.$ : 水密板から上段扉スキンプレート 下端までの距離）としたときの振動発生領域が示されて いる. 


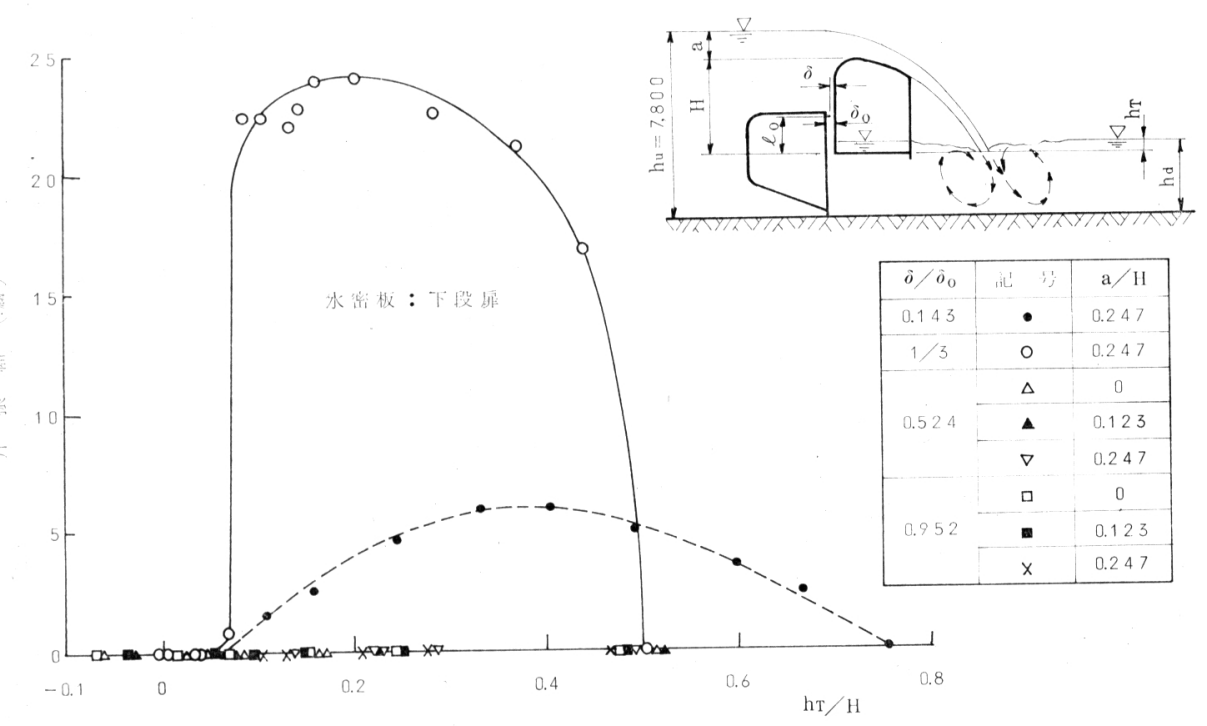

図一14 中間止水部のすきま 8 と振動の関係

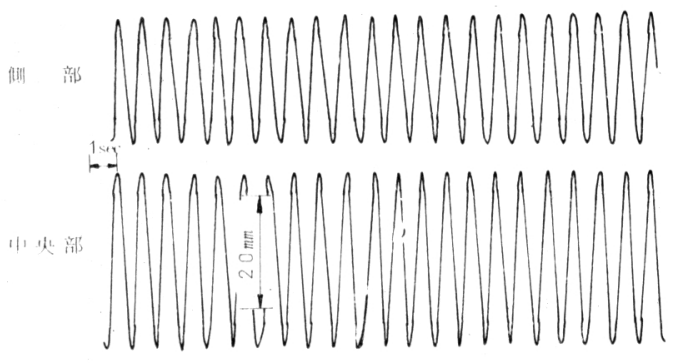

a) $11=0.247$, ni, $11=0.442$, id io $0.3 / 3$

図一15 漏水に伴う振動記録波形

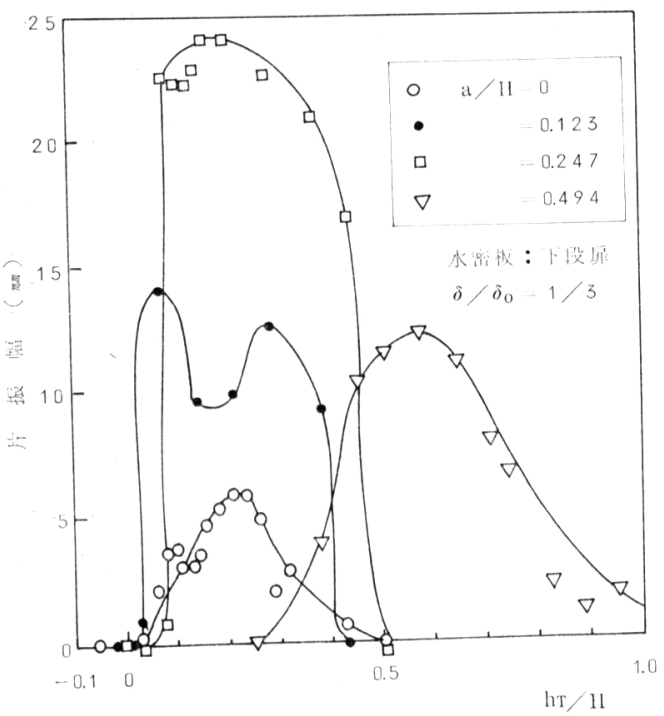

図一16 振幅と $h_{T} / \boldsymbol{H}$ の関係

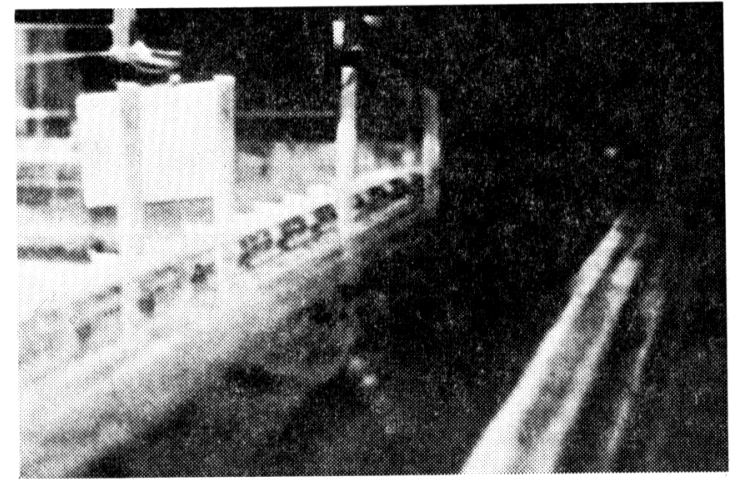
$\begin{array}{cl}\text { 写真一3 } & \text { ゲート直上流の水面状況 }(a / H=0, \\ & \left.h_{T} / H=0.16, \delta / \delta_{0}=1 / 3\right)\end{array}$

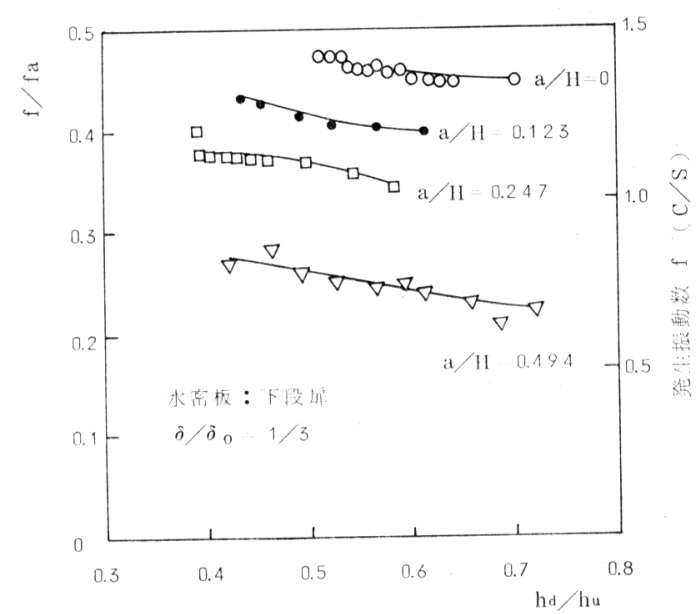

図-17 発生振動数 $f$ と $\boldsymbol{h}_{d} / \boldsymbol{H}$ の関係 


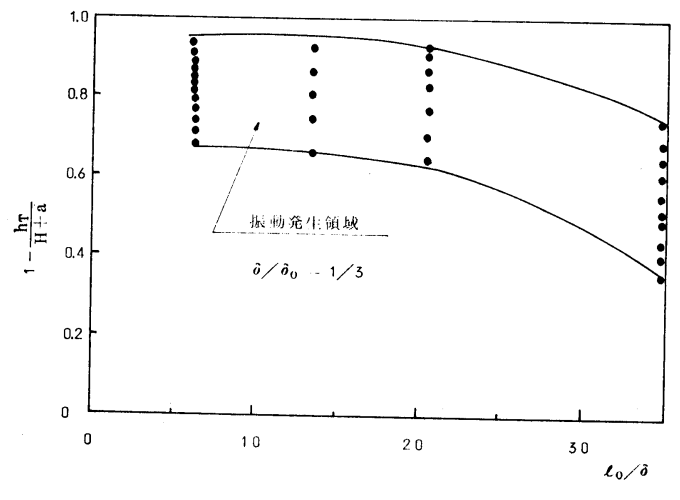

図一18 振功の発生領域

これらの図より，次のことが判明する.

(1) 下流水位が上段扉スキンプレート下端よりも上昇 してくると, ゲート開度が大幅に変化しても振動は発生 する・

(2) 振動の発生振動数は, 上下流水位差が同じである にもかかわらず, ゲート開度が大きくなるにつれて低下 する.このことは, この種の振動が水密板先端から離脱 する周期的な渦によって発生する強制振動ではなく, 振 動系自体の影響を受ける自励振動であることを示すもの である.したがって, 図一17に示された発生振動数は, 系の固有振動数にほぼ一致するとみることができ，ゲー 卜開度や下流水深が増すにつれて発生振動数が低下する のは, 水の付加犋量の増大によるためであると考えられ る.

(3) 漏水に伴う振動の発生範囲は，上下段扉のラップ する長さが増すほどすなわち開度が大きいほど広くなる 傾向がある.

c）水密板の取付位置の効果

水密板の取付位置が，これまでに述べてきた振動にど
きま $\delta_{u}$ や下流水位が種々変化しても, この種の振動は 発生しないことが認められる. さらに, 水密板を上下 段扉の両方に取付けた場合にも， $\delta_{\boldsymbol{u}}$ をある限られた値 $\left(\delta_{u} \leq \delta_{0} / 1.4\right)$ にすれば, 漏水しているにもかかわらず, この種の振動は発生しないことがわかる.

以上，a） c) で述べてきた振動特性から，漏水に伴 う振動は, 薄い漏水水脈の不安定性に起因する自励振動 であると考えられる.すなわち，下段扉上部に取付けら れた水密板のすきまから流下する薄い漏水水脈により水 密板下側の圧力が低下寸ると, その水脈が下段扉側に引 き寄せられて上段扉がたわみ，水密板のすきまをせばめ る. すると水密板下側の圧力は上昇し, 上段扉の弾性力 によって再びそのすきまが大きくなり，以後これを綝り 返すという現象であると考えられる.

したがって，上下段扉のスキンプレートで囲まれた流 路内の流れの安定化をはかることがこの種の振動を防止 する有効な方法であり，上段扉スキンプレート下端にの み水密ゴムを取付け, 流れの支配断面を下流端にもって くることも 1 つの方法である. しかし，このようにする と, 上段屝に作用する水圧が増大し不経済な設計となる ため, 実際上は水密ゴムを下段扉に, $\delta_{u} \leqq \delta_{0} / 1.4$ を満足 するようなしゃ水板 (水密板) を上段扉スキンプレート 下端に取付ける方が合理的であるといえる.

\section{4. 微少開度下端放流および漏水に伴う振動に ついての理論解析}

下端放流を行う 1 段式ローラゲートにおいて, 開度が 非常に小さいときに振動が発生する場合には，ゲートの 動きによって流水の止水効果がかなり強く効いてきて, 水の流入量と流出量の差によって力が生じてくるものと のように影響してくるかを調べ てみる.水密板を上段扉スキン プレート下端にのみ取付けて, そのすきま $\delta_{u}$ を種々変化させ た場合および水密板を下段扉上 部と上段屝スキンプレート下端 の両方に取付け, $\delta=\delta_{0} / 3=-$ 定の状態で $\delta_{\boldsymbol{u}}$ を変化させた場 合の 径間中央における 振幅 と $h_{T} / H$ の関係を示すと図一19 のようになる.この図には水密 板を下段扉にのみ取付けて, $\delta=\delta_{0} / 3$ のときの振幅 と $h_{T} / H$ の関倸も示されている.これよ り, 水密板を上段扉スキンプレ 一ト下端にのみ取付けると, 寸

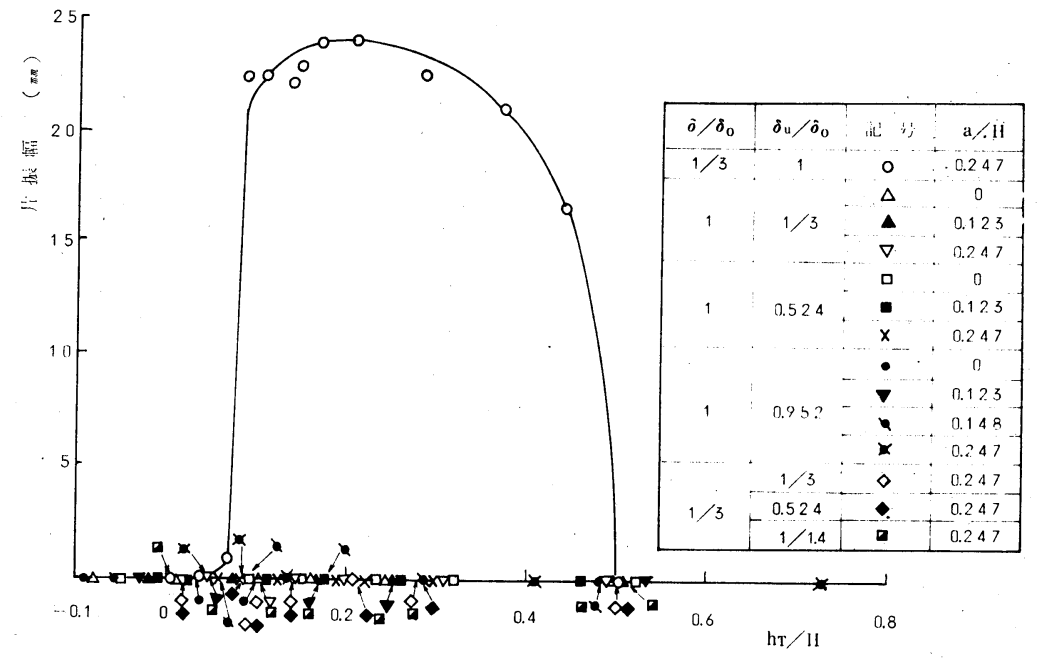

図一19 水密板の取付位目と振功の䦦保 


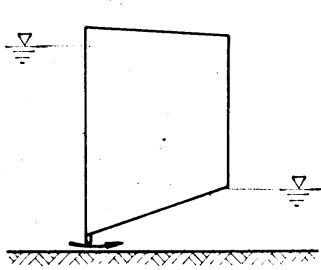

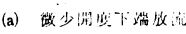

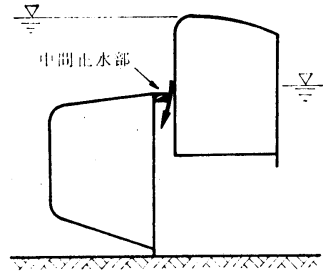

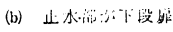

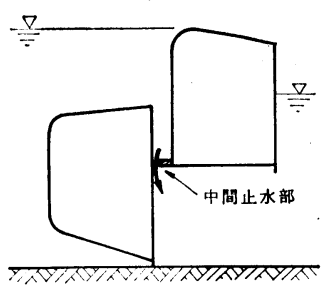

(c) 上水部が上段屝
図一20微少闻度下端放流と中成止水部からの㧚水
水脈の不安定性は, この流れの変 動に対応するわけである.このよ らな考え方によって，ここではこ の Wake の変動をゲートの運動 と結びっけて理論的な表現をす る.この場合, 長径間シェル構造 ローラゲートは，一般にねじれ㣚 性が非常に大きく回転運動が無視 できると考えられるから ${ }^{8)}$, 以下，
考えられる.このことは， 2 段式ローラゲートの漏水に 伴う振動についても，水密のが 図一20 (b) のように下 段扉上部に取付けられた場合に発生し, 図一20 (c) のよ うに上段扉スキンプレート下端に取付けられた場合には 発生してこないことを考えると, 図一20 (a) と同じよ うな考えで進めてもよいと考えられる。すなわち，図一 20 (b) を $90^{\circ}$ 回転させると図一20 (a) とほぼ同じ流れ の状況になってくることがわかる. 以下，このような振 動現象の理論解析モデルを発展させてみる. 実験は弾性 相似模型によって行っているので, たわみ振動と㣚性振 動が合成された形で発生している. しかし，自励振動の 原因はゲートの固有振動と水の流れの関係で発生するの で, 解析上简素化するため剖体運動としての解析をし, 実験との比較は固有振動（たわみと㣚性）について考え ることにする.

\section{（1）体稳変化を考えた理論解析モデル}

ここで扱うような小開度での流れにおいては,ゲート に作用する力をどのように表現するかが大きなポイント になってくる. 大開度および流水の中におかれたゲート の場合には, 抗力, 揚力を使った表現方法を適用するこ とも比較的容易であるが（揚力係数，抗力係数などのデ 一タも多( $\left.{ }^{11}\right)$. このような小開度においての流体力は, 水路底面または上段扉のスキンプレートの効果が大きな ファクターになってきており, 抗力, 揚力の考え方を使 らのは，あまり適当であるとは考えられない.

そこでこここでは次のような考え方を展開することに する.すなわち, ゲート下端から放流した場合, 流れが ゲートリップからはく離し，ゲート底板下に Wake が 形成される. この Wake の大きさは, ゲート底部の形 状と放流条件によって決まるものと考えられる．ゲート 底板に作用する圧力は, この Wake 中の圧力に支配さ れることは自明であり, また, ゲートが振動している場 合にも, この関係は不変であると考えてよいので, この Wake の消長が圧力変動を生じさせることになる．また は逆に考えて流れの変動に伴ってこの Wake が消長 し, それに合致する形で圧力の変動を生じさせると考え てもよい. 前記の実験結果のをころで指摘している薄い
上下方向の運動のみ着目する.

\section{a) 流量}

ゲート下端から流出する単位幅あたりの流量 $q$ は, 流量係数を $c$, 流速を $v_{0}$ とすれば,

$$
\begin{aligned}
q & =c a v_{0} \ldots \ldots \ldots \ldots \ldots \\
& =c a \sqrt{2 g h_{u}} \ldots \ldots \ldots \ldots \\
& =c a \sqrt{2 g\left(h_{u}-h_{d}\right)} .
\end{aligned}
$$

で与えられ, 式 (1)' および式 (1)" は, それぞれ自由流 出および潜り流出についての表現である.

b） ゲートの運動に伴う流量の変化

流れの応答の速度は, ゲートの運動に比べて遅いと考 えられるので, ゲート開度の増減中においても流速はほ とんど一定に保たれているとみなされる.

したがって, 本来式 (1) より,

$$
d q=c \cdot a \cdot d v_{0}+c \cdot v_{0} \cdot d a
$$

となるはずであるが, $d v_{0}$ は $d a$ に比べて 微少である とみなされているから, 式 (2) は,

$$
d q=c v_{0} d a
$$

と表わされる.

c） ゲートの運動に伴う Wake の体積の増減 ゲートの運動の始まった瞬間においては, 流れの追随 が難しいことは先の仮定にいれてあるところであるが, この場合にも同様に考えることにする.

いまゲートが上方へ運動するときを正とし，図一21 に示すように開度 $a$ から上方へ $y$ だけ移動したための Wake の体積増減量を $d V_{1}$, ゲートリップ付近におい て生ずるそれを $d V_{2}$ とすれば, ゲートの運動に伴ら体 積の増減は,

$$
\begin{aligned}
d V & =d V_{1}-d V_{2} \\
& =B y-d V_{2} \text { (B: ゲートの厚さ) } \\
& \fallingdotseq B y
\end{aligned}
$$

として, $d V_{2}$ は $d V_{1}$ に比べて微少であると考える.

d）流量変化を考虑した Wake の体積変化

式 (4)の $y$ は, 実は時間の経過に伴って刻々変化し ているので, 運動している状態で考える必要がある.

したがって, $d t$ 時間で $y$ が生じたとすれば,

$$
y=\dot{y} d t
$$

と表わさ机る、七たがって，式 (3)，“(4) および式（5) 


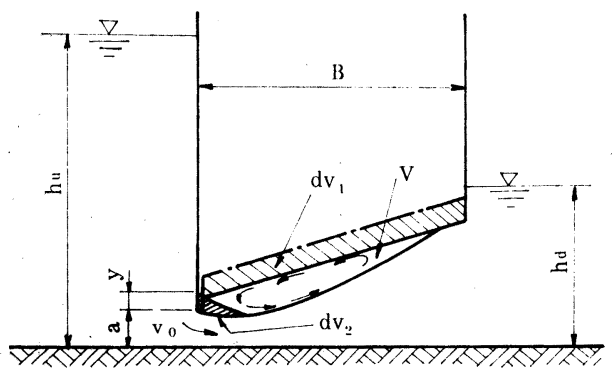

図-21 Wake の体樌增減モデル

より,

$d V=c v_{0} d a \cdot d t+B \dot{y} d t$

また， $d a=y$ であることを考えると，

$$
\frac{d V}{d t}=c v_{0} y+B \dot{y}
$$

を得る.

e）振動外力

式 (6) のような Wake の体積変化が運動の各瞬間に 作用しているときに, 変動圧力 $P$ の大きさとしては, もともとあった Wake の体積 $V$ との関係で,

$$
P=\frac{d V}{d t} \cdot \frac{1}{V} \cdot \beta
$$

と表現することにする.ここに， $\beta$ は体積弹性係数に相 当するが， $\left(\mathrm{kg} / \mathrm{cm}^{2}\right)(\mathrm{sec})$ の単位をもつことになる.

したがって，振動外力は次のようになる.

$$
F=P B L(L: \text { 径間 })
$$

f) 振動方程式

質量 $M$, 減衰係数 $R$ およびばね定数 $k$ とすれば, 振動方程式は,

$$
M \ddot{y}+R \dot{y}+k y=F
$$

で表わされる. そこで,

$$
2 \gamma=R / M, \omega_{n}^{2}=k / M
$$

とすれば, 次のようになる.

$$
\ddot{y}+2 r \dot{y}+\omega_{n}^{2} y=(B L / M)(\beta / V)\left(c v_{0} y+B \dot{y}\right)
$$

さらに,

$$
(B L / M)(\beta / V) \cdot c v_{0}=\omega_{1}{ }^{2},(B L / M)(\beta / V) \cdot B=2 \gamma_{1}
$$
とおくと,

$$
\ddot{y}+2\left(r-r_{1}\right) \dot{y}+\left(\omega_{n}^{2}-\omega_{1}^{2}\right) y=0
$$

で表わされる.

したがって, 式 (10) は $r<r_{1}$ のときに不安定とな るわけであるが，この条件では前述の実験結果と比較す ることができない.

\section{（2）进動量の変化を考えた理論解析モデル}

（1）で述べた解析モデルでは，ゲート開度や流量等に 関倸した不安定条件がでてこないことがわかった。この 原因江式（7）に示した 外力の表示方法にある。すなわ
ち,この式は体積弾性係数によって示されるごとく, 水 の圧力波としての扱いになっており, ウォーターハンマ 一のように非常に速い速度で伝わる現象を示している.

そこで,ここでは運動量の変化すなわち流れのしゃ断 によるカに着目することにする.

いま, ゲートが開度 $a$ から $d y / d t$ の速度で $y$ だけ 降下したと考えるとき，流れをさえぎった流量 $d V_{0}$ は，

$$
\begin{aligned}
d V_{0} & =v_{0} y L \\
& =Q_{0} y / a\left(Q_{0}: \text { 流量 }\right)
\end{aligned}
$$

で表わされる.一方, 運動量の方程式は，

$$
F \cdot \Delta t=\Delta(M \cdot v)
$$

であるから，振動外力は，この運動量によって生ずる力 のスキンプレートに作用する成分と考えられるので,

$$
F=\eta \cdot \rho Q_{0} \cdot\left(\frac{y}{a}\right) \cdot \frac{d y}{d t}
$$

で与えられる.ここに， 動外力と流れのしゃ断による力の比を表わす無次元数で

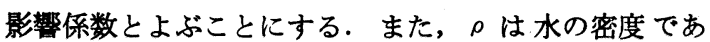
る.

そこで, 運動方程式は,

$$
M \ddot{y}+R \dot{y}+k y=\eta \cdot \rho Q_{0} \cdot\left(\frac{y}{a}\right) \cdot \frac{d y}{d t}
$$

で表わされる．ここで， $\eta \cdot\left(\rho Q_{0} / M a\right)=\alpha$ とおき, 式 (8) の関倸より次式が得られる.

$$
\ddot{y}+2 r \dot{y}+\omega_{n}^{2} y-\alpha y \cdot \frac{d y}{d t}=0 .
$$

この式は非線形であって，次のように書き直せる.

$$
\ddot{y}+(2 r-\alpha y) \dot{y}+\omega_{n}^{2} y=0
$$

式（13）において問題の項は第 2 項であり, 単純に考 えれば, $y=\varepsilon \sin \omega_{0} t$ のような微少振動があったとする と,

$$
2 \gamma-\alpha \varepsilon \sin \omega_{0} t<0
$$

によって不安定振動が発生することになる.すなわち，

$$
2 \gamma-\alpha \varepsilon<0
$$

のときに不安定な振動となることが考えられる。

したがって, 不安定条件として,

$$
2 r<\eta \cdot \frac{\rho Q_{0}}{M} \cdot \frac{\varepsilon}{a}
$$

を得る・ただし，笪密には式（13）を解く必要がある。

このように, 運動量の変化を考えた解析モデルの場合 には, 不安定条件の中に流量, 質量, 振幅, ゲー卜開度 および減衰係数が含まれている。

そこで, 前述の実験結果と不安定条件, 式 (14) との 関係について調べてみると图一22 のよ5になる. 図中， ・印はゲート下端から放流したときの微少開度 $\left(a / h_{u}=\right.$ 0.008）において自励振動が発生した場合，×印は $a / h_{u}$ Z0.1において强制振動が発生した場合を示している. また，。印は中間止水部からの漏水に伴ら振動 $\left(\delta / \delta_{0}=\right.$ 


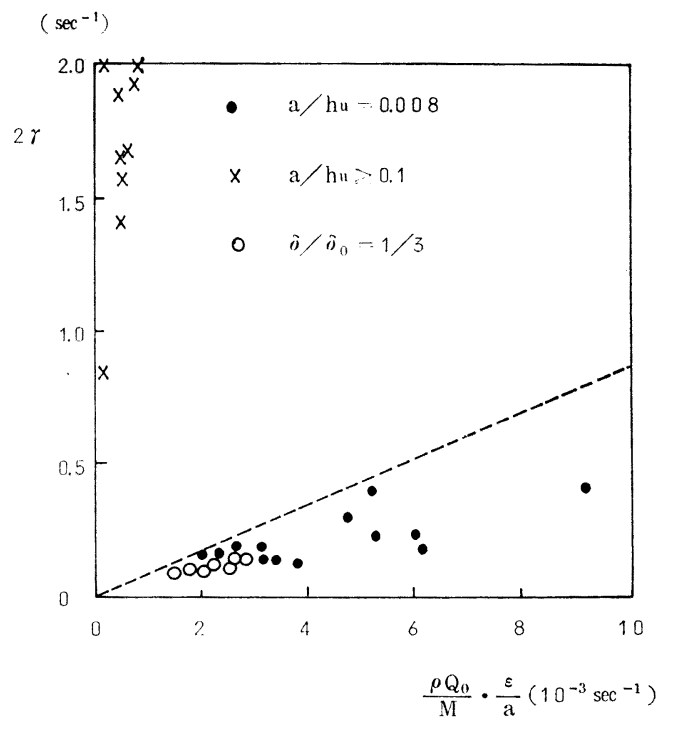

図一22 $2 \gamma$ と $\left(\rho Q_{0} / M\right)(\varepsilon / a)$ の関係

1/3）が発生した場合を表わしている.

図一22 から，微少開度下端放流に伴う振動と漏水に 伴う振動は, 類似の現象としてみることができ, $a / h_{u}$ Z 0.1 の下端放流に伴う振動とは明らかに異なっているこ とがわかる。 また，不安定条件，式 (14)を満足する影響 係数 $\eta$ は，図一22 の破線で示寸直線の勾配であり， $\eta \fallingdotseq$ 85 となる. これは, 振動外力の大きさが流れのしゃ断 による力の 85 倍程度であることを意味している.

\section{5. 結 論}

以上 1 段式ローラゲートの下端放流および 2 段式ロー ラゲートの中間止水部からの漏水に伴う振動特性につい て述べてきた.

この研究から得られた結果をまとめると，

（1）スキンプレートが上流側に配置され，底板が $20^{\circ}$ 程度傾斜したゲートの下端放流に伴ら振動は, $a / h_{u}$ $\geq 0.1$ の開度で発生する振幅の小さい比較的不規則な振 動と $a / h_{u} \approx 0.01$ の微少開度で発生する振幅の大きい規 則振動飞分類される。

（2）前者はゲート直下流に生ずる波動によって誘起 される強制振動である，後者はゲート底板下一流入する
薄い水脈の不安定性に起因する自励振動で，台形シルを ゲート底板下に設けたり，あるいは流れのはく離点をゲ 一ト下流縁に固定すれば防止できる.

（3）漏水に伴う振動は，下流水位が上段扉底板上り も高く, しかも下段扉上部にのみ取付けられた水密ゴム と上段扉スキンプレートの間にある限られたすきま（う ऽ。 $\left.\hat{o}_{0} / 3\right)$ が生じたときにのみ発生する.

（4）この振動は，水密部のすきまから流下する薄い 漏水水脈の不安定性汇起因する自励振動である. 漏水し ていてもこれを防止できる有効かつ合理的な方法は，水 密ゴムを下段扉に， $\delta_{u} \leq \delta_{0} / 1.4$ としたしゃ水板を上段 屝スキンプレート下端に設けることである.

（5） 運動量の変化を考えた解析モデルょり，不安定 条件 $2 r<\eta\left(\rho Q_{0} / M\right)(\varepsilon / a)$ が誘導され，微少開度下端 放流および漏水による自励振動が発生するときには，影 響係数 $\eta \approx 85$ となる.

（6） 実験結果をもとに解析された $2 r$ と $\left(\rho Q_{0} / M\right)$ $(\varepsilon / a)$ の関係より, 微少開度下端放流および漏水に伴う 振動は類似の現象としてみることができ， $a / h_{u} \geq 0.1$ の 下端放流に伴ら振動とは明らかに異なっていることが認 められる.

最後に, 本研究にあたり多大のご指導をいただいた林 栄港博士（建設技術研究所）ならびに実験の遂行に終始 協力していただいた山田 稔君（石川島播磨重工業(株) 鉄構基本設計部) に深く感謝する次第である.

\section{参 考 文 献}

1) Petrikat, K. : Vibration tests on weirs and bottom gates, Water Power, Part One, Feb. 1958.

2）荻原国宏 : 開水路中の スルースゲートの报動に関する基 礎的研究, 土木学会論文集, 141 号, 1967.

3）林 泰造・朝田真弘：ローラーダートの振動特性に関す 万研究, 第 23 回土木学会年次学術講演会, 昭 43.

4) Campbell, F.B. : Vibration Problems in Hydraulic Structres, Proc. A.S.C.E. (HY 2), Mar. 1961.

5) Naudascher, E. : Vibration of gates during overflow and underflow, Proc. A.S.C.E. (HY 5), Sep. 1961.

6) Petrikat, K. : Vibration tests on weirs and bottom gates, Water Power, Part Three, April, 1958.

7) Petrikat, K. : Vibration in bottom outlet structures of dam excited by elastic control gate seals, I.A.H.R. Eleventh International Congress, Leningrad, 1965.

8）荒木正夫：長径間ゲートの振動解析および水理実験と䒠 测との比較, 第 25 回土木学会年次学術講演会, 昭 45 .

(1978.2.9. 受付) 